\title{
Características de consumo para salas de cine de arte en México (Consumption characteristics for Mexican art movie theaters)
}

\section{'David Fernando Lozano Treviño}

\begin{abstract}
This research paper analyzes the character of cinema as a work of art and its relation in the cinematographic markets. It details the way in which Film Production Organizations (OPC) works on the aesthetics ways in movies. It shows the development of the art cinema within the Mexican film industry and the spaces where filmmakers and OPC interacts with distribution and exhibition companies. Film genres are mentioned and how they work as a cultural tools. Some benefits to the audience cinema art are exposed. It runs a correlation between the desires of the spectators for movies in art halls that stimulates among the audience the appreciation of arts, reflection, learning and entertainment with the monthly expenditure in pesos to watch films that places art before any other feature of the cinema.
\end{abstract}

Key words: art, culture, income, film production organizations, spectators.

JEL:

Resumen: El presente artículo de investigación analiza el carácter del cine como obra de arte y su relación en los mercados cinematográficos. Detalla cómo las Organizaciones de Producción Cinematográficas (OPC) trabajan en la estética de la película. Se presenta el desarrollo del cine de arte dentro de la industria cinematográfica mexicana y los espacios existentes donde los directores y las OPC se relacionan con distribuidores y exhibidores. Se mencionan los géneros cinematográficos y su funcionamiento como herramienta cultural. Algunos beneficios para el público del cine como arte son expuestos. Se ubica la correlación que hay entre los deseos de los espectadores porque las películas que se proyectan en salas de arte estimulen entre los espectadores el aprecio a las artes, la reflexión, el aprendizaje y el entretenimiento con el gasto mensual en pesos para ver películas que antepongan el arte sobre cualquier otra característica del cine.

Palabras clave: arte, cultura, espectadores, ingresos, organizaciones de producción cinematográficas. 


\section{Introducción}

El arte es una manifestación humana que expresa una visión personal y desinteresada interpretando lo real o lo imaginado con recursos plásticos, lingüísticos, visuales o sonoros. Canaliza las expresiones sensibles del ser para que lleguen a otros, e incluso que trasciendan el espacio y el tiempo (Lozano, D. \& E. Treviño, 2014 , p. 273). Los sentimientos se plasman mediante formas, sonidos, imágenes 0 letras que las personas interpretan cognitivamente, para transformar ese significado en algo sensitivo (Platón, 2009, p. 344); o viceversa, un sentimiento se trabaja de manera cognitiva para que pueda ser plasmado de una manera inteligente con la pretensión de que sea entendido y después sentido por el espectador, el escucha, el lector o el público.

El arte es el conjunto de preceptos y reglas necesarios para hacer bien cualquier cosa (Flores, A. et al. 2009, p. 89). Por definición, se engloba a cualquier actividad que esté bien desarrollada. Cuando se habla de bellas artes, se refiere a la arquitectura, escultura, pintura, música, literatura, teatro y, al objeto de estudio de la presente investigación, el cine, las cuales son actividades y expresiones cuya finalidad es resaltar la belleza.

El concepto de belleza ha resultado polémico en cuanto a su conceptualización. ¿Qué es bello? Para algunos una imagen fotográfica que muestra a una mujer pidiendo limosna puede resultar bella pero para otros no así. Platón reflexionó que la belleza era más que la apariencia física y se preguntó si lo bello era la causa del bien o si solamente se atribuía a los placeres de la vista y el oído. De lo que estaba seguro es que era algo difícil de alcanzar y por lo que se tenía que trabajar y sacrificar mucho.

Aristóteles consideraba el orden y la exactitud como componentes que definen la belleza. San Agustín dijo que la belleza consiste en la unidad y orden que surgen de la complejidad. Este orden comprendería el ritmo, la simetría o las proporciones. Tomás de Aquino tuvo un concepto más amplio, pues además de incluir la armonía y la calidad o brillantez, consideraba la integridad. Finalmente, Epicuro proponía que la belleza es todo aquello que nos llena de placer.

Los valores, son creencias criterios y convicciones que sirven para comprendernos a nosotros mismos y dar un sentido de interdependencia con los demás (Badii, M., A. Pazhkh \& R. Foroughbakhch, 2004, p. 94). Dentro de la gama de valores, encontramos los valores estéticos, los cuales se definen como aquellos que permiten mantener un equilibrio cognitivo y sensitivo y una armonía 
en la belleza interior y exterior (Lozano, D. A. Almaguer \& K. Rodríguez, 2015, p. 30). Las artes se orientan en gran medida a este tipo de virtudes pues estimulan el placer al momento que se les aprecia. Además, equilibran nuestro ser.

Entonces, el cine es el arte de contar historias por medio de imágenes y sonido (Lozano, D. \& E. Treviño, 2014, p. 279). Es bello pues ordena o armoniza el caos, infundiendo en los espectadores deleite, equilibrio, reflexión y aprendizaje. Mediante el cine, los directores como artistas principales expresan ideas, emociones, una visión del mundo, percepciones y sensaciones que no son explicables de otro modo y que, sin embargo, fortalecen ideas o cambian opiniones en los espectadores además de divertirlos y entretenerlos.

El cine se clasifica de dos formas:

- Popular. Se aprende de manera empírica y suele ser muy práctica y funcional. Este tipo de películas preservan técnicas aprendidas en talleres de producción y refleja costumbres y tradiciones mediante las imágenes apreciadas y los sonidos percibidos.

- Académico. Es el cine que sigue las reglas estéticas y las teorías establecidas. Se valora la diferencia más que la semejanza. Una obra sería revisada en múltiples ocasiones, además de que su elaboración, requirió un extenso trabajo previo.

Por otro lado, los componentes de las obras cinematográficas son:

1. Tema. Se refiere al significado: pobreza, guerra y esperanza, son algunos ejemplos.

2. Concreto o abstracto. Lo primero describe todo aquello en lo que todos podemos estar de acuerdo en cuanto a su figura o significado. Lo abstracto será aquello que pierde su referencia con lo convencional, es algo que no deja claro su significado y a veces es utilizado en el cine de arte.

3. Signo. Es la cosa representada tal cual. Por ejemplo, si un actor viste de blanco, simplemente cubre su cuerpo conforme a las reglas sociales.

4. Símbolo. Aquí se le confiere otro significado a lo que se aprecia. En el caso anterior, el actor que viste de blanco refleja un estado de paz, tranquilidad y amistad.

5. Composición. Es propiamente el orden que se les da a los elementos que comprenden a una obra de arte y que genera una satisfacción a la vista 0 al oído. 
Las artes cinematográficas han influido mucho en el desarrollo económico y cultural de las naciones. Generan empleos e ingresos para las Organizaciones de Producción Cinematográficas (OPC), los distribuidores y exhibidores, principalmente. Funcionan, a su vez, como herramientas educativas mediante documentales o clips académicos usados en las escuelas; buscan el equilibrio interno y externo de los espectadores y estimulan la reflexión de ideas, opiniones y pensamientos que el director simboliza en la película.

\section{Planteamiento del problema}

Independientemente del carácter económico que desempeña el cine, conformador de una industria generadora de amplias riquezas en los Estados Unidos, India, Nigeria, entre otros, incluyendo México, por su alto potencial comercial, no se debe dejar pasar por alto su esencia artística.

Acuñado por Ricciotto Canudo, teórico del cine, como séptimo arte, las OPC comerciales, y por supuesto las de arte, comprenden sus cualidades creativas de arte popular o académico, que además de invitar al público al entretenimiento, estimulan a la reflexión, el aprendizaje y la apreciación de la estética cinematográfica.

Ahora, las OPC, independientemente su orientación, deben crear productos que en teoría busquen la satisfacción del público, por lo tanto, herramientas que permitan conocer la correlación que hay entre los deseos de un espectador por que las películas que se proyectan en salas de arte estimulen entre los espectadores el aprecio a las artes y estética cinematográficas, la reflexión de los contenidos de la película, el aprendizaje y el entretenimiento con la cantidad de pesos que destina dicho espectador para ver películas que antepongan el entretenimiento, el carácter educativo y cultural, su carácter artístico y su esencial de estimulador de la reflexión; es conveniente para la toma de decisiones de las OPC, los productores, directores e investigadores que aborden temas similares.

De esta forma se amplía el conocimiento que las OPC pudieran tener de los patrones de consumo de los espectadores cinematográficos tanto por lo que desea que se proyecte en salas de arte para él, o ella, como para el resto del público y cuánto impacta esto último en sus propias decisiones de consumo más allá de la satisfacción propia que espera de una película. Por ejemplo, un espectador determinado prefiere el arte y la estética en las películas. Está consciente 
que éstas también deben divertir a los espectadores. Al momento de que se documenta sobre algunas películas determinadas que tienen altos grados estéticos pero no entretiene al público, ¿seguirán en pie sus mismas intenciones y niveles de gastos para dichos filmes?

\section{Objetivo}

Identificar la correlación que hay entre los deseos que los espectadores tienen porque las películas que se proyectan en salas de arte estimulen entre los espectadores el aprecio a las artes y estética cinematográficas y la cantidad destinada en pesos mensualmente para asistir a ver películas que antepongan el carácter artístico sobre cualquier otra característica del cine.

Conocer la relación existente entre los deseos que los espectadores tienen porque las películas que se proyectan en salas de arte estimulen entre los espectadores la reflexión de los contenidos de la película o lo que acontece en la misma y la cantidad destinada en pesos mensualmente para asistir a ver películas que antepongan el carácter artístico sobre cualquier otra característica del cine.

Ubicar si entre los deseos que los espectadores tienen porque las películas que se proyectan en salas de arte estimulen entre los espectadores el aprendizaje se relaciona con la cantidad destinada en pesos mensualmente para asistir a ver películas que antepongan el carácter artístico sobre cualquier otra característica del cine.

Identificar la correlación que hay entre los deseos de los espectadores tienen porque las películas que se proyectan en salas comerciales estimulen entre los espectadores el arte y la cantidad destinada en pesos mensualmente para asistir a ver películas que antepongan el carácter artístico sobre cualquier otra característica del cine.

\section{Hipótesis}

H1: A mayor deseo de los espectadores porque las películas que se proyectan en salas de arte estimulen entre los espectadores el aprecio a las artes y estéticas cinematográficas, mayor el gasto mensual en taquillas para ver películas que antepongan el arte sobre cualquier otra característica del cine. 
H2: A mayor deseo de los espectadores porque las películas que se proyectan en salas de arte estimulen entre los espectadores la reflexión de los contenidos de la película o lo que acontece en la historia, mayor el gasto mensual en taquillas para ver películas que antepongan el arte sobre cualquier otra característica del cine. H3: A mayor deseo de los espectadores porque las películas que se proyectan en salas de arte estimulen entre los espectadores el aprendizaje, mayor el gasto mensual en taquillas para ver películas que antepongan el arte sobre cualquier otra característica del cine.

H4: A mayor deseo de los espectadores porque las películas que se proyectan en salas de arte estimulen entre los espectadores el entretenimiento, mayor el gasto mensual en taquillas para ver películas que antepongan el arte sobre cualquier otra característica del cine.

\section{Las artes cinematográficas y la industria en México}

El cine es el arte del tiempo, de las imágenes y los sonidos, un arte que construye los movimientos que relacionan los cuerpos entre sí en un determinado espacio (Alvarado, C. 2015, p. 52). La imagen cinematográfica no desaparece cuándo ha pasado el cuadro, la escena o la misma película en pantalla; sino que gracias a su estimulación de la sensibilidad del espectador, y la capacidad que éste tiene de transformarlo en material cognitivo, opera como instrumento narrativo y discursivo de lo que los directores y productores creen sobre la realidad.

La particularidad del cine en el arte, con respecto a las otras seis, es que las condiciones de su producción son siempre exteriores a él mismo. El cine nunca puede estar aplicado sobre sí, necesita elementos exteriores para componerse técnica y narrativamente (Arias, J. 2006, p. 110). Se entiende que el cine no crearía otro arte independiente, sino que sustrae de las otras seis lo mejor de ellas.

El cine consiste en estructuras narrativas puras donde se aprecian los secretos del uso del tiempo, la construcción de caracteres y la efectividad dramática de ciertas decisiones de los directores. Para mayor economía deben preferirse las imágenes visuales a las palabras mientras que estas imágenes puedan comunicar la impresión buscada (Keizman, B. 2011, p. 255). De hecho, los diálogos deben ser el último recurso para transmitir información, pues estos se captan por medio del oído, mientras que el sentido favorito del hombre es la vista; es decir, preferimos ver antes que escuchar. 
Como obra de arte, el cine representa un verdadero reto para las OPC y en particular para los directores como principales artistas. Lograr transmitir ideas, pensamientos y opiniones por medio de historias cinematográficas y que estas impacten en los espectadores es difícil. Hacerlo de manera exitosa se traduce en altos ingresos en taquillas, crítica positiva, recomendaciones de boca en boca entre la audiencia o premios obtenidos en certámenes. El impulso que las OPC llevan en su ópera prima no siempre es posible sostener si los directores no trabajan en formas acertadas para llegar al público. Aun y cuando estén comprometidos en el proyecto original deben abrirse a trabajar con productores que tengan una visión amplia de lo que desean ver los espectadores y aquello que rechazarían.

La mayoría de los directores nunca volverán a dirigir un largometraje. Por ejemplo, según el Anuario Estadístico de Cine Mexicano, del Instituto Mexicano de Cinematografía, para el 2015 hubo 53 óperas primas, 37 por ciento de la producción (Figura 1). Para las segundas y terceras obras, juntas, se contabilizaron 54 películas mientras que para aquellos directores que con más de cuatro películas se observaron 37 filmes (Figura 2).

Figura 1. Número de óperas primas en México del 2010 al 2015

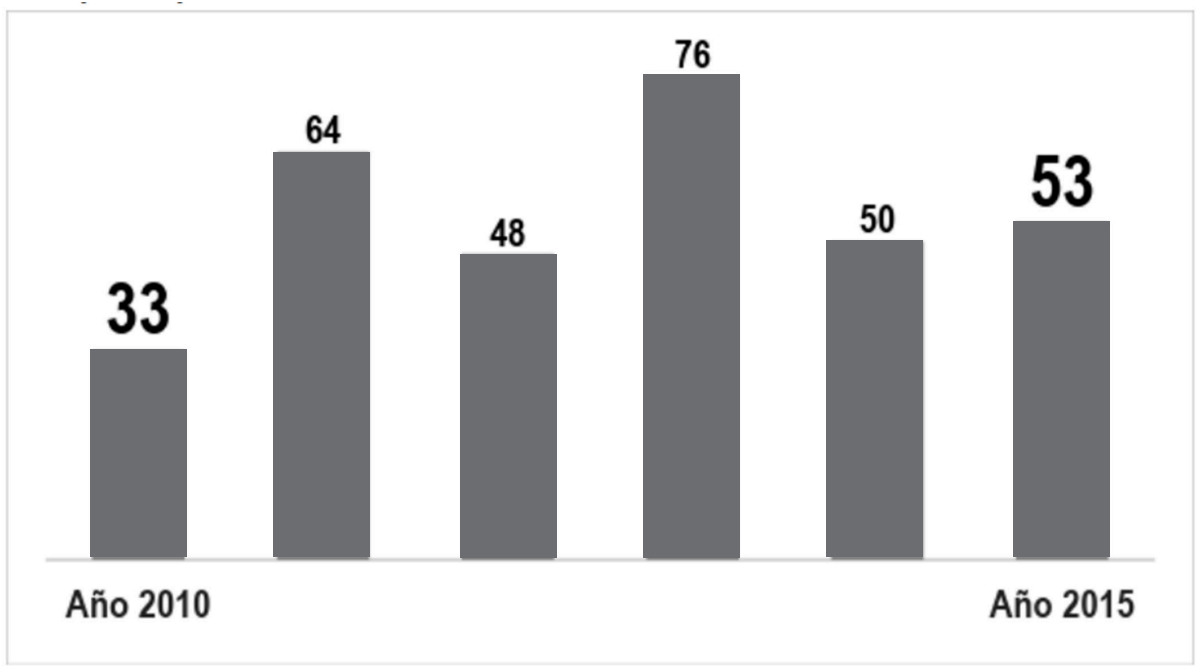

*Elaboración propia con información del Anuario Estadístico de Cine Mexicano, 2015. 
Figura 2. Número de películas por trayectoria del director en 2015

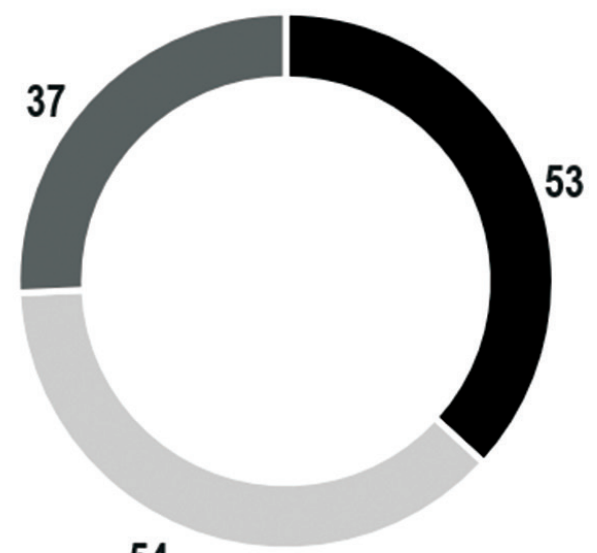

54

- Ópera prima $\quad$ Segundas y terceras obras $\quad$ Cuatro obras o más

En México, el cine como arte, empodera tanto a las OPC como a los productores, directores y actores principalmente. Desmitifica los medios comerciales y hasta políticos pues el público lo asocia con la intelectualidad, cultura y el empresariado. Les da fuerza colectiva a los realizadores mediante la difusión. Gracias al cine como arte, las OPC documentan, educan, promueven la reflexión, asimilan los acontecimientos y se resisten a la política. Mediante el cine, los directores y productores fácilmente pueden crear otra realidad, al menos en su percepción sensible (Zorroza, M. 2007, p. 71).

El arte cinematográfico se expresa transmitiendo los estilos de vida de una región, la manera en que se ve al ser humano y su comportamiento en donde el objetivo es lograr que el espectador lo viva desde su butaca. El espectador, como consumidor, necesita historias. Historias que vivan a través de otras existencias.

Las OPC tienen como objetivo crearlas y vendérselas. Esa es su misión como empresas vendedoras de arte partícipes de una industria activa en el sistema económico y donde el arte y la cultura desempeñan un papel dinámico. Por ejemplo, el cine, junto con los medios audiovisuales, la televisión, la radio e internet, generó en 2013 el 4.8 por ciento de los puestos de trabajo ocupados en la cultura los cuales fueron de un millón 018 mil 456. 
El cine se ubicó por encima del teatro, literatura, escultura, pintura, fotografía y la música (Figura 3).

Figura 3. Puestos de trabajo ocupados por la cultura

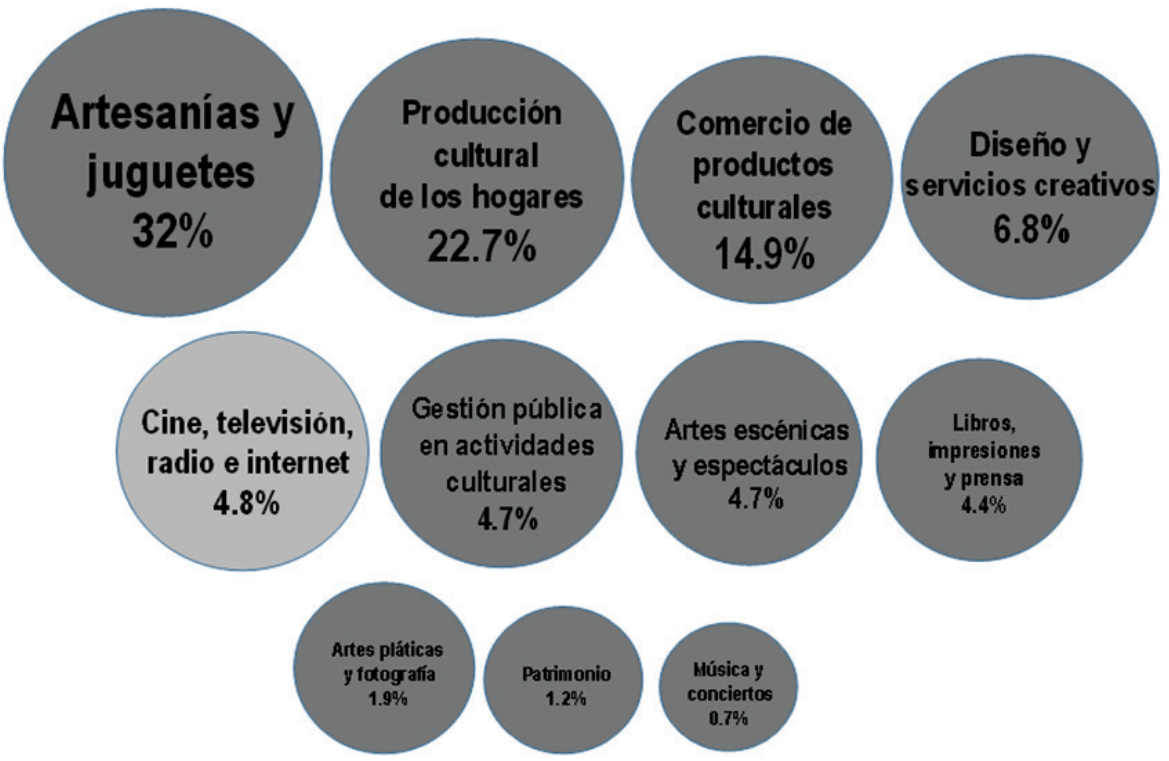

*Elaboración propia con información Instituto Nacional de Estadística y Geografía.

Además de que los festivales de cine son espacios que permiten que las OPC y los artistas interactúen con exhibidoras y distribuidoras que potencialmente pudieran comercializar las películas; fungen como una ventana del cine como arte hacia la sociedad que desea apreciarlo como tal y disfrutar de su estética.

La industria no puede dejar a un lado la naturaleza artística del cine por encima de su vía económica como generadora de empleos, pago de impuestos, productora de bienes de exportación, etcétera. De hecho, esta característica inherente al cine ha tenido importante crecimiento. En el 2015 se realizaron 119 festivales de cine en México, superando los 109 celebrados un año anterior y por mucho los 10 que apenas se organizaron en 2000. El crecimiento y la difusión del cine como arte entre el público agarró fuerza del 2010 a la fecha, pues el 60 por ciento de los festivales iniciaron hace cinco años. Prácticamente todas las entidades federativas tuvieron al menos un festival con excepción de Nayarit y Guerrero los cuales no organizaron ninguno. La Ciudad de México celebró 33, Guanajuato nueve y Jalisco ocho. 
Figura 4. Festivales por tema en México en 2015

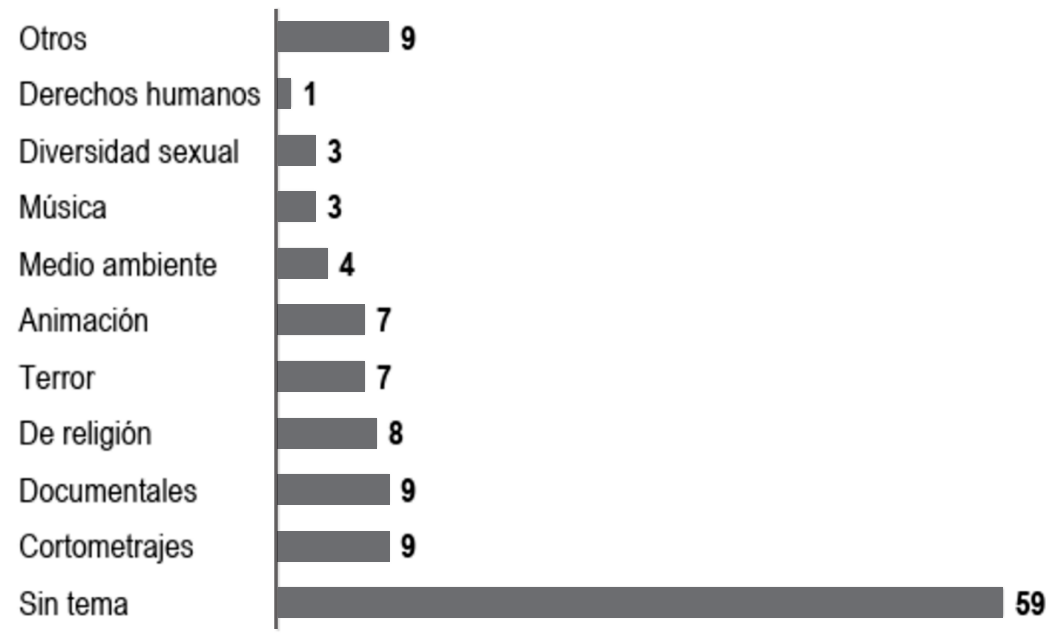

*Elaboración propia con información del Anuario Estadístico de Cine Mexicano, 2015.

Los festivales de cine también permiten la generación de espacios de experimentación y expresión. Por ejemplo, las principales temáticas proyectadas fueron sobre cortometrajes lo que brinda salas y pantallas para los estudiantes 0 aquellos cineastas que producen filmes para darse a conocer o transmitir un mensaje.

En cuanto a la expresión, los festivales proyectaron en gran medida temas específicos relacionados con la religión, ocho; cuatro para el medio ambiente; tres para la diversidad sexual y uno para los derechos humanos. Nueve se realizaron principalmente para proyectar exclusivamente cortometrajes (Figura 4).

Por otro lado, los premios han resultado de importancia para las OPC, la industria y los mismos espectadores, principalmente porque por medio de los asistentes a dichos festivales o por las evaluaciones de jurados o profesionales del cine, se califica la calidad estética de las películas.

En México, los filmes que más premios obtuvieron en el extranjero fueron Trémulo con ocho; Desde allá siete y Comienzo del tiempo con seis cada uno (cuadro 1). Cabe señalar que, los premios no son garantía para obtener espacios en salas comerciales, pues ninguna de las tres películas fue exhibida en complejos de este tipo durante el 2015. 
Dichos indicadores reflejan la conciencia que tiene el público del cine como obra de arte, y probablemente los deseos que pudiera aguardar para que las películas estimulen dicha característica entre los espectadores.

Tabla 1. Películas mexicanas con más premios en el extranjero en 2015

Trémulo

Desde allá

El comienzo del tiempo

Cantinflas

Casa blanca

Te prometo anarquía

*Elaboración propia con información del Anuario Estadístico de Cine Mexicano, 2015.

\section{El cine como herramienta cultural para los espectadores}

El cine como herramienta cultural o educativa puede cumplir tres objetivos (García, M. 1997, p. 305):

- La transmisión y fijación de conocimientos, con lo que supone el refuerzo del aprendizaje.

- El fomento de espíritu crítico.

- La capacidad del diálogo.

El lenguaje cinematográfico tiene como finalidad transmitirle al público una serie de hechos que pueden ser verídicos o simple ficción con la finalidad de que sean apreciados y reflexionados. García, M (1997) considera que una película presenta personajes a los que les pasa una serie de eventos por los cuales, se transporta a los consumidores a un universo hecho por las OPC y sus directores con base en ideas, pensamientos, opiniones y referencias. Un punto fuerte del cine es que los elementos culturales pueden ser transmitidos al público rápidamente, contrario a lo que pasa con la lectura.

La situación cultural del cine y del video es un objetivo apto para el estudio de las leyes del pensamiento y la acción del hombre (Lozano, D. 2015, p. 200). El cine en esencia, más allá del primer sentimiento que captemos de carácter comercial, busca hacer reflexionar a la audiencia sobre sí mismo y sobre la sociedad. Su carácter racional desde la elaboración del guion hasta el montaje mismo le da un elemento cultural. A través del cine, el hombre ha logrado trascender. 
El carácter cultural del cine, que incluyen las OPC, se da en tres dimensiones:

1. Físico. Se revela la relación funcional que se da entre las acciones y los objetos reflejados y los actores. Considera cómo el filme muestra los elementos físicos del lugar donde suceden los acontecimientos: el sitio, el clima, los objetos con los que interactúan los personajes, etcétera.

2. Histórico. Se revela la relación que se da entre los personajes y las fuerzas socioculturales plasmadas en la película, es decir, cómo queda determinada por el trasfondo cultural de los personajes en cuanto a la educación, religión, costumbres, economía o gustos.

3. Sicológico. Se revela la identidad transferida por el director, productor, actores o demás miembros del equipo de filmación a la película y que queda evidente a través de la historia, fotografía, actuación, edición, sonido o cualquier otro elemento comprendido en la producción cinematográfica.

Las OPC, crean productos que son simbólicos, fruto de la creatividad humana y patrimonio cultural de una sociedad al englobar su identidad. En estos productos es imposible disociar valor económico de valor cultural y cada vez se vuelve más difícil mantener los históricos límites entre ambos (Arrese, Á. 2004, p. 23). El cine crea una industria cultural particular que genera tantas riquezas económicas y culturales como la hollywoodense, india o nigeriana.

El cine, es un componente sustantivo en la enseñanza, puede usarse como apoyo o como lección didáctica. Funciona como un eje de transmisión del conocimiento mientras que el espectador tiene la capacidad para extraer el mejor sentido y disfrute de la naturaleza del séptimo arte (Amar, V. 2009, p. 133). E mismo autor considera que el cine es una herramienta de suma importancia pues desarrolla la imaginación de los espectadores produciendo en ellos su capacidad de entender el presente para comprender mejor el futuro. Es inherente que las historias que se cuentan en el cine, están ligada a los acontecimientos pasados, la sociedad y la cultura del país que las produce y el origen de los personajes del mismo filme.

Las OPC han explotado esta naturaleza propia del cine. Por ejemplo, en África, fue utilizado como un medio de evangelización e instrucción, principalmente por medio de películas de ficción educativas y la filmación de documentales (Quevedo, V. 2011, p. 10). 
En la actualidad, Nigeria, el tercer país que más películas produce en el mundo, por medio de Nollywood, crea filmes tomando la cultura americana plasmada en los filmes de Hollywood y los tropicaliza a los estilos de vida del continente africano. Genera importantes ingresos por medio de taquillas, venta de DVD y distribución por plataformas en internet. A menudo, estos filmes son vistos como una representación de las realidades africanas (Adesolean, A. 2014, p. 15).

Ahora, los apoyos del gobierno son importante para las OPC que producen películas de arte o culturales, pues estas no consideran las fuerzas del mercado del todo. La obra cinematográfica de carácter cultural desempeña un papel análogo al de la obra comercial aunque las mismas OPC deberían comprenderla como una obra industrializada para después pedirle que se comporte como obra cultural. Independientemente de ser obra de arte, los productores tendrán que responder a ciertas expectativas administrativas, comerciales y financieras que de no ser sustentables, destinarán a las OPC a la desaparición (Cárdenas, J. 2014, p. 631). Primero se debe trabajar para captar masas de espectadores que como consumidores garanticen ingresos en taquillas, para así difundir conocimientos, ideas y formas en que el artista ve la vida, entre ellos.

El cine le permite a los espectadores reflexionar sobre acciones que no hacen en su vida cotidiana, aunque lo pudieran lograr. Esto se logra mediante historias imposibles pero verosímiles en lugar de aquellas que sean posibles pero increíbles. La manera en que se refleja el arte y la cultura se puede hacer por los diferentes géneros los cuales tiene características particulares (McKee, R. 2011, p. 108):

1. Historia de amor. Se da cuando los artistas pretenden contar historias de amor romántico.

2. Película de horror. La OPC pretende infundir entre los espectadores ideas o formas terroríficas de ver el mundo. Se pueden dividir en tres: Misterio. La fuente de terror es sorprendente pero está sujeta a una explicación racional. Sobrenatural. Los fenómenos mostrados en la historia son irracionales o fantasmagóricos. Supermisterioso. Es una mezcla donde el público puede creer o no creer lo terrorífico de lo que ve en el filme.

3. Época moderna. Los personajes se enfrentan a los poderes políticos. Los directores pretenden infundir ideas contrarias a las que se comunican por medio del gobierno. 
4. Vaqueros. Suceden en pueblos, rancherías, haciendas y enfrentan problemas de la vieja forma para ser solucionados.

5. Guerra. Puede darse a manera en que el director pretende oponerse a los actos bélicos, o bien, como en algunas películas hollywoodenses o norcoreanas, pueden estar a favor de ellos.

6. Madurez. Se reflexiona sobre la experiencia que la edad da a las personas.

7. Redención. En este caso, la película gira en torno a un cambio moral del protagonista, infundiendo entre el público ideas hacia la modificación de acciones o al perdón hacia aquellos que han cambiado sus estilos de vida.

8. Punitiva. El director pretende concientizar sobre los castigos que se recibiría si las buenas obras se vuelven malas.

9. Pruebas. Historias del poder de la voluntad ante la tentación de rendirse.

10. Educativa. Este género gira en torno a un cambio profundo en la visión que tiene el protagonista de la vida, de las personas o de sí mismo de lo negativo a lo positivo

11. Desilusión. Un profundo cambio en la visión del mundo, de positiva a negativa.

12. Comedia. La OPC ridiculiza su entorno.

13. Policiaca. Son historias contadas y relacionadas con asesinatos, detectives, espionaje, prisioneros, entre otros. Su finalidad es relatar hechos criminales, criticar comportamientos sociales o burocráticos 0 mostrar acciones de los delincuentes.

14. Drama social. Identifica los problemas de la sociedad como la pobreza, educación, enfermedades, construyendo una historia que proponga una solución.

15. Acción. Incorpora ideas que buscan estimular en el espectador el protagonismo para solucionar problemas y convertirse en héroe social.

16. Histórico. Narra hechos acontecidos en la historia de la humanidad, mostrando la visión de los directores, guionistas y productores.

17. Biografía. Se centra en una persona encontrando significado a la vida del mismo.

18. Docudrama. Se centra en acontecimientos recientes en lugar de en el pasado. 
19. Falso documental. Pretende basarse en hechos o recuerdos, se comporta como un documental o una autobiografía, pero es totalmente ficticio. Satiriza la hipocresía de las instituciones.

20. Musical. Presenta una realidad en la que los personajes bailan y cantan sus historias.

21. Ciencia ficción. Es la representación del futuro hipotético según el realizador.

22. Deportivo. Se utiliza cando el deporte funciona como llave de cambio para las acciones de los personajes.

23. Fantasía. Los guionistas y directores juegan con el tiempo, espacio y lo físico, curvando y mezclando las leyes de la naturaleza y de lo sobrenatural.

24. Animación. Este género enfrenta al público con las leyes de la metamorfosis universal, donde cualquier cosa se puede convertir en algo distinto.

25. Arte y ensayo. Aunque acuñado, se refiere a las películas que abordan cualquier género antes mencionado pero que innovan con ideas diferentes y maneras en las que se cuentan las historias. La idea no siempre queda clara para el espectador mientras que el director no necesariamente pretende que ésta sea captada por el público.

Mediante los géneros, las OPC intentan culturizar a los espectadores, es decir, influir en sus estilos de vida, estimularlos a apreciar el arte y la estética cinematográfica, educarlos o documentarlos, así como entretenerlos y divertirlos.

\section{Expectativas de consumo en salas de cine de arte}

El cine es una forma de representación social, cultural, política y artística del mundo en el que nos ha tocado vivir y tiene un potencial educativo y artístico que muy pocas veces ha sido estudiado y desarrollado pero dichas cualidades son esperadas por los espectadores cuando asisten a salas de cine de arte (González, G. 2013, p. 61). El público desea que la película le deje algo: conocimientos, reflexiones, ideas, etcétera. Ubica al cine como un medio potente en la generación de conocimientos, poniendo al director y los productores como referentes en el tema que se aborda. De hecho, es una herramienta muy útil en la promoción y publicidad de los filmes la leyenda "de los creadores de..." debido al renombre y experiencia que han adquirido los realizadores. 
Los espectadores en salas de arte, construyen situaciones pasadas, presentes y futuras mediante lo que aprecian, la vida de los personajes principales, los cambios enfrentados por tomas de decisiones determinadas o conflictos nacionales, acontecidos en la historia del filme. Son ideas o información que las OPC les ha hecho llegar.

Las siguientes ideas ilustrativas son esperadas por el público que aprecia cine de arte o educativo (Dale, E. 1966, p. 86):

- Aprender sobre el tema que se aborda para aumentar sus conocimientos

- Adquirir ciertas ideas que le permitan mejorar sus destrezas

- Adquirir opiniones que les permitan cambiar su estilo de vida, motivarse o mejorar sus actitudes.

- Mejorar y retener temas previamente aprendidos.

- Estimular sus enseñanzas artísticas, filosóficas, educativas, o según el tema específico que se aborde

- Reflexionar en la búsqueda de resolver problemas determinados.

Un punto fuerte del cine es que motiva a los espectadores a platicar sobre el tema una vez que la película ha terminado o bien, si alguien habla de ella antes de la proyección, los contenidos y las imágenes son apreciadas mejor (Fajnzylber, V. \& J. Hurriaga 2013, p. 98). El cine se vuelve un motivador a la discusión sana y productiva.

En la televisión, las películas documentales más demandadas son aquellas que están relacionadas con temas sobre contaminación ambiental, degradación de ecosistemas, el crecimiento humano desmedido y la vida animal (Sancho, J., A. Vilchis \& D. Gil 2010, p. 670), temas que generan conciencia social. Las OPC pueden encontrar áreas de oportunidad en temas relacionados con los derechos humanos. Los documentales, además de ser películas que requieren menor técnica fotográfica, son de bajo presupuesto y mediante una acertada dirección, edición y diseño de sonido, se logra captar la atención del espectador, transmitirle información y mantenerlo satisfecho.

El cine, es una realidad cultural, y como tal, influye en las actitudes, conocimientos, emociones, gustos e intereses de los espectadores (García, M. 2002, p. 358). El cine de arte es capaz de impulsar modas entre los espectadores. Por otro lado, la ficción permite preparar al público para afrontar situaciones semejantes en la vida real para encaminarlas a convertirse en seres expertos, igualmente, la empatía que se puede crear con los personajes, permite entender de 
mejor manera los problemas a los que se enfrentan y las soluciones empleadas. Las películas facilitan el entendimiento de las complejidades de ciertos procesos, como diagnósticos médicos o construcciones arquitectónicas, especialmente por la escenificación del lenguaje no verbal, es decir, le permite al espectador ver las cosas, los acontecimientos (Gómez, A. \& H. Estrada 2015, p. 29).

El cine de arte, aquel que está comprometido con la estética y que busca el equilibrio tanto en el espectador como en el cosmos entero, tiene como característica una posición contrahegemónica, considerando como hegemónico el sistema de producción del cine comercial. Estos directores y productores, demuestran un compromiso ético y político con el mundo que les rodea. Las OPC trabajan considerando que el cine es una herramienta que puede contribuir a la transformación social (Galán, M. 2012, p. 1124). Los cineastas se inclinan por desarrollar temas que tratan problemas que afectan los sectores populares con el fin de impactar en la conciencia de los espectadores, para que comprendan, piensen, descubran, tomen conciencia de la situación y emprendan acciones transformadoras. Además, ellos mismos pueden difundir las ideas entre los demás espectadores o entre los miembros de la sociedad. Este tipo de películas se proyecta en mayor medida en salas alternativas o de arte.

Algunos beneficios de la apreciación de películas que se centren en el arte y la cultura están (Surmeli, H. 2012, p. 1013):

1. Incremento en el interés por las ciencias

2. Mayor entendimiento de contenidos científicos

3. Beneficia la actitud de los espectadores hacia el arte y la cultura

4. Incentiva el éxito hacia el conocimiento

5. Permite la visualización de temas abstractos

6. Mejora la creatividad

7. A los estudiantes les permite que relacionen los aprendizajes dentro de diversas materias y entre diferentes unidades de aprendizaje

8. Despierta a explorar sobre diferentes áreas del conocimiento, el arte o el deporte

9. Enfatiza la necesidad de actuar de manera ética en la ciencia

10. Inspira a los espectadores para crear obras de arte

11. Equilibra el comportamiento de la audiencia en su vida cotidiana

12. Permite reflexionar sobre temas de la vida

13. Estimula a la acción para la solución de problemas 
Para las OPC, las historias cinematográficas no sólo son lo que se cuenta, sino también la manera en que se cuentan. Si su contenido es un cliché, la forma de narrar también lo será (McKee, R. 2011, p. 23). Punto a favor del cine de arte, sobre el cine comercial, pues si la visión de los directores y productores es original, el diseño de la película como producto será único. El autor propone algunos axiomas sobre el carácter artístico, cultural, e incluso, comercial del cine:

- Principios, no normas. Los principios se limitan a lo que ha funcionado desde que se recuerda, el cine no debe seguir un modelo de una obra bien hecha sino que debe estar bien hecho conforme a los principios de las artes cinematográficas, es la riqueza estética del mismo.

- Propone formas eternas y universales, no fórmulas. En las artes no existen prototipos, sino una variedad de películas bien hechas. El reto de las OPC es entusiasmar, cultivar e inspirar al público.

- Propone arquetipos. Las artes cinematográficas desvelan experiencias humanas universales que se visten de una expresión única y de una cultura específica. Deben tener contenido.

- Es minucioso. Para las OPC, la producción de películas requiere tiempo y diligencia: largas horas para revisar el guión, efectuar trabajos acertados de preproducción, estar abierto a trabajar con fotógrafos, editores, productores, directores y guionistas para efectuar los mejores cortes, es decir, orientarse a ser meticuloso para encontrar la mejor manera en que se puede contar la historia.

- Es real. Las historias de éxito están producidas por OPC que, de manera realista, entienden a lo que se pueden enfrentar en materia estética, de producción, económica, entre otras y con base en eso se esfuerzan para encontrar la manera apropiada de contar la historia.

- Es consciente. Aunque se trate de cine de arte, las OPC tiene en mente que son parte de un sistema de mercado, que para sobrevivir, les obliga a transmitir su arte de una forma que impacte en el público. Lo conveniente es trabajar a conciencia con el equipo.

- Respeta al público. El cine tiene la capacidad de atrapar al público, pero no debe de subestimarse. Los espectadores son sensible a productos que no fueron pensados, en lo absoluto, en sus necesidades no en la manera en que pudieran comprender los temas o mensajes que se pretenden transmitir. 
- Original. La innovación y lo que genera moda tiene un atractivo particular para el público. Las películas son referentes para la sociedad, mientras que los directores, productores y actores adquieren poder para influir en los demás.

Los espectadores consumen películas al grado que se ha convertido en una fuente de inspiración estética dinámica. Le da sentido a la vida además de que equilibra tanto el mundo interno como externos del ser humano. La finalidad de las OPC es motivar a la intelectualidad y al entretenimiento. De hecho, los consumidores de películas de arte, esperan que los cineastas vivan la vida y que por medio de sus obras, hagan que ellos desde las butacas también la puedan vivir.

\section{Diseño del instrumento}

Se aplicó una encuesta encaminada a determinar en qué medida desean los espectadores que las películas que se proyectan en las salas de arte estimulen:

- El aprecio a las artes y estética cinematográficas

- La reflexión de los contenidos de las películas o lo que acontece en la historia

- El aprendizaje

- El entretenimiento

En el otro extremo se les cuestionaba a los encuestados la cantidad de dinero en pesos que destinan al mes para ver películas que antepongan el entretenimiento sobre cualquier otra característica del cine; el carácter educativo y cultural; el carácter artístico y; el carácter de estimulación de la reflexión. Las preguntas se respondieron con base en una escala de 0 al 10, donde 0 es "Nada" y 10 "Totalmente", o bien, el monto total que destinaban a la compra de boletos en taquillas mensualmente, según sea el caso.

\section{Metodología de la investigación}

En la búsqueda de visualizar los deseos de los espectadores por que se proyecten en salas de arte películas que estimulen entre el púbico el aprecio a las artes, la reflexión de los contenidos de la película, el aprendizaje o el entretenimiento y la cantidad de recursos monetarios que destinaban al mes para ver películas que antepongan una de las características previamente detalladas en el marco 
teórico, se aplicó una encuesta en Monterrey y su área metropolitana. Se considera que los espectadores de dicha región tienen un comportamiento similar a los de Occidente en general y a los de México en particular. Para obtener la muestra se obtuvo la población total del estado de Nuevo León para el 2010 que fue de cuatro millones 653 mil 458, según datos del Instituto Nacional de Estadística y Geografía en el país. Igualmente, se basó en datos del mismo instituto que reflejan que el 88 por ciento de los habitantes viven en el área metropolitana seleccionada, es decir, cuatro millones 095 mil 043.

Para obtener respuestas lo más precisas posibles, el estudio se realizó con espectadores que ya tuvieran un criterio propio para seleccionar un filme al momento de asistir a las salas cinematográficas así como aquellos que hayan externado su interés potencial por ir al cine sin importar la película que fueran a ver. Se encuestó a espectadores mayores de 15 años, los cuales representan el 70.6 por ciento de la población, arrojando una cifra de dos millones 891 mil 100.

Así, se procedió a determinar el tamaño de la muestra con un error de estimación (E) del $10 \%$ y un grado de confianza del 95 por ciento.

$E$ (Error de estimación) $=10 \%$

$p=0.5$

$q=0.5$

$\mathrm{N}$ (Población) $=2,891,107$

Con un $95 \%$ de confianza

Obtenemos:

$$
\begin{gathered}
(1)\left(z^{2} p q\right) / E^{2} \\
n=(1.962 \times 0.5 \times 0.5) \div(0.1)^{2} \\
n=96
\end{gathered}
$$

Cercano a los 100

Por lo tanto, 100 encuestas fueron las que se contestaron con proporciones similares para hombres, mujeres, edades y estratos socioeconómicos.

Las preguntas tomadas en cuenta, de manera específica para este estudio, fueron: 
1) En qué medida desea que las películas que se proyectan en salas de arte estimulen entre los espectadores:

- El aprecio a las artes y estética cinematográficas

- La reflexión de los contenidos de la película o lo que acontece en la historia

- El aprendizaje

- El entretenimiento

2) Cuánto destina en pesos para asistir a ver películas que antepongan:

- El entretenimiento sobre cualquier otra característica del cine

- El carácter educativo y cultural del cine como cualquier otra característica

- El carácter artístico del cine sobre cualquier otra característica

- El carácter de la estimulación de la reflexión del cine sobre cualquier otra característica

Las variables independientes son:

- Los deseos de un espectador por que las películas que se proyectan en salas de arte estimulen entre el público el aprecio a las artes y estéticas cinematográficas $\left(X_{1}\right)$.- Se refiere al grado en que un espectador quiere que una película que se proyecta en salas de arte transmita al público un mensaje del director como artista que pretenda equilibrar el cosmos o el comportamiento humano.

- Los deseos de un espectador por que las películas que se proyectan en salas de arte estimulen entre el público la reflexión de los contenidos de la película $\left(\mathrm{X}_{2}\right)$.- Se refiere al grado en que un espectador quiere que una película que se proyecta en salas de arte, transmita al público un mensaje que haga que se "quede con algo", es decir, que la haga pensar sobre un tema determinado, cambiar o reforzar sus creencias, opiniones, ideas o comportamientos.

- Los deseos de un espectador por que las películas que se proyectan en salas de arte estimulen entre el público el aprendizaje $\left(X_{3}\right)$.- Se refiere al grado en que un espectador quiere que una película que se proyecta en salas de arte, eduque o refuerce los conocimientos del público.

- Los deseos de un espectador por que las películas que se proyectan en salas de arte estimulen entre el público el entretenimiento $\left(X_{4}\right)$.- Se 
refiere al grado en que un espectador quiere que una película que se proyecta en salas de arte, divierta al público.

Por otro lado, como variable dependiente tenemos:

- El gasto en boletos en taquilla para películas que antepongan el entretenimiento $\left(\mathrm{y}_{1}\right)$.- Se da cuando los espectadores adquieren boletos para ver películas cuyo objetivo principal es divertir al público más que buscar que éste aprecie el filme, reflexione o se cultive, aunque puede tener dichas características como objetivos secundarios. Lo mismo se preguntó para aquellas películas que antepongan el carácter educativo y cultural, el carácter artístico y el carácter de estimulación de la reflexión, por lo que existe y2, yз y y4.

Lo siguiente se analizó mediante tres regresiones lineales múltiples representadas con las ecuaciones de la 2 a la 5 :

$$
\begin{aligned}
& y_{1}=\beta 0+\beta_{1} X_{1}+\beta_{2} X_{2}+\beta_{3} X_{3}+\beta_{4} X_{4}+e \\
& y_{2}=\beta 0+\beta_{1} X_{1}+\beta_{2} X_{2}+\beta_{3} X_{3}+\beta_{4} X_{4}+e \\
& y_{3}=\beta 0+\beta_{1} X_{1}+\beta_{2} X_{2}+\beta_{3} X_{3}+\beta_{4} X_{4}+e \\
& y_{4}=\beta 0+\beta_{1} X_{1}+\beta_{2} X_{2}+\beta_{3} X_{3}+\beta_{4} X_{4}+e
\end{aligned}
$$

donde:

$X_{1}=$ Los deseos de un espectador por que las películas que se proyectan en salas de arte estimulen entre el público el aprecio a las artes y estética cinematográficas.

$\mathrm{X}_{2}=$ Los deseos de un espectador por que las películas que se proyectan en salas de arte estimulen entre el público la reflexión de los contenidos de la película o lo que acontece en la historia.

$\mathrm{X}_{3}=$ Los deseos de un espectador por que las películas que se proyectan en salas de arte estimulen entre el público el aprendizaje.

$\mathrm{X}_{4}=$ Los deseos de un espectador por que las películas que se proyectan en salas de arte estimulen entre el público el entretenimiento.

$\mathrm{y}_{1}=$ Gasto en pesos que se destina al mes para ver películas que antepongan el entretenimiento sobre cualquier otra característica del cine.

y2= Gasto en pesos que se destina al mes para ver películas que antepongan el carácter educativo y cultural sobre cualquier otra característica del cine.

$\mathrm{y}_{3}=$ Gasto en pesos que se destina al mes para ver películas que antepongan el carácter artístico sobre cualquier otra característica del cine. 
y4= Gasto en pesos que se destina al mes para ver películas que antepongan el carácter de la estimulación de la reflexión sobre cualquier otra característica del cine.

\section{Resultados de la investigación}

En la Tabla 2 se aprecia un coeficiente de determinación R2 de 0.01 es decir, el grado en el que el modelo explica el comportamiento de la variable dependiente con respecto a las independientes o bien, la relación que hay de las $x$ con la $y$. Con el valor arrojado, el modelo no es confiable. Se entiende que el gasto mensual que se hace en taquillas para ver películas que antepongan el entretenimiento sobre cualquier otra característica, no tiene relación con la medida en que la muestra desea que las películas que se proyectan en salas de arte estimulen entre los espectadores el arte y la estética cinematográfica, la reflexión de los contenidos, el aprendizaje y el mismo entretenimiento; es decir, el consumidor que adquiere un boleto en taquillas de las salas de arte, según los resultados del presente estudio, lo seguirá haciendo sin importar sus propios deseos de que si las películas proyectadas en dichas salas estimulan o no estimulan las características conceptualizadas por las variables independientes (ecuación 2). Probablemente, el consumidor toma la decisión de compra en salas de arte para películas que antepongan el entretenimiento únicamente teniendo en mente los propios beneficios que recibirá sin importar si las películas proyectadas en dichas salas de arte estimulan el aprecio a las artes y la estética cinematográficas, la reflexión, el aprendizaje o logra entretener a los demás espectadores.

Tabla 2. Estadísticas de regresión para la ecuación 2

\begin{tabular}{lr}
\hline Estadístico & Valor \\
\hline Coeficiente de correlación múltiple & 0.12467823 \\
Coeficiente de determinación $\mathrm{R}^{\wedge} 2$ & 0.01554466 \\
Error típico & 175.772824 \\
Observaciones & 103 \\
\hline
\end{tabular}

Para la Tabla 2 y por lo tanto la ecuación 2 , se observan resultados similares. Coeficiente de determinación $\mathrm{R}^{2}$ de 0.02 . El modelo no es confiable. Así, el gasto mensual que se hace en taquillas para ver películas que antepongan el 
carácter educativo y cultural del cine sobre cualquier otra característica, no tiene relación con los deseos de los espectadores por que se proyecten películas en salas de arte que estimulen entre los espectadores el arte y la estética cinematográfica, la reflexión de los contenidos, el aprendizaje y entretenimiento. Nuevamente, se pudiera determinar que a pesar de que los consumidores deseen que se estimulen las características comprendidas en las variables independientes, en las salas arte, si éstas lo hacen o por el contrario no lo hacen, el consumo no se verá afectado (ecuación 3).

Por lo que, al igual que lo visualizado en la Tabla 1 y ecuación 2, éste toma la decisión de compra únicamente teniendo en consideración sus propias necesidades aun y cuando deseen, o les resulte indiferente, si se estimula entre los demás espectadores las funcionalidades de las películas.

Tabla 3. Estadísticas de regresión para la ecuación 3

\begin{tabular}{lr}
\hline Estadístico & Valor \\
\hline Coeficiente de correlación múltiple & 0.17099927 \\
Coeficiente de determinación $\mathrm{R}^{\wedge} 2$ & 0.02924075 \\
Error típico & 81.7836457 \\
Observaciones & 103 \\
\hline
\end{tabular}

El cuestionamiento relacionado con el gasto mensual que se hace en taquillas para ver películas que antepongan el carácter artístico del cine sobre cualquier otro obtuvo un coeficiente de determinación mayor con una $\mathrm{R}^{2}$ de 0.02 . El modelo solo explicaría en un dos por ciento los movimientos de la variable dependiente dados por las independientes. Tampoco es confiable (Tabla 3; ecuación 4).

Finalmente, en la Tabla 4 y la ecuación 5 se refleja un coeficiente de determinación $R^{2}$ de 0.007 donde no existe relación entre las $x$ con la $y$. El gasto mensual que se hace en taquillas para ver películas que antepongan la estimulación de la reflexión sobre cualquier otra característica, no tiene relación con la medida en que los espectadores desean que las películas que se proyectan en salas de arte estimulen entre los espectadores el arte y la estética cinematográfica, la reflexión de los contenidos, el aprendizaje o el entretenimiento. 
Tabla 4. Estadísticas de regresión para la ecuación 4

\begin{tabular}{lr}
\hline Estadístico & Valor \\
\hline Coeficiente de correlación múltiple & 0.1505879 \\
Coeficiente de determinación $\mathrm{R}^{\wedge} 2$ & 0.02267672 \\
Error típico & 102.90503 \\
Observaciones & 103 \\
\hline
\end{tabular}

Tabla 5. Estadísticas de regresión para la ecuación 5

\begin{tabular}{lr}
\hline Estadístico & Valor \\
\hline Coeficiente de correlación múltiple & 0.08471578 \\
Coeficiente de determinación $\mathrm{R}^{\wedge} 2$ & 0.00717676 \\
Error típico & 123.880545 \\
Observaciones & 103 \\
\hline
\end{tabular}

Entonces, ya sea que desee o que le de igual, que se proyecten en salas de cine de arte películas que estimulen entre los demás espectadores el aprecio a las artes y estética cinematográfica, la reflexión de los contenidos de la película o lo que acontece en la historia, el aprendizaje o el entretenimiento; la medida de dichos deseos para con los demás consumidores, no afectarán sus patrones de consumo de boletos en taquillas de esas mismas salas de arte.

\section{Conclusiones}

El arte es una manifestación humana que expresa una visión personal y desinteresada interpretando lo real o imaginado con recursos plásticos, lingüísticos, visuales o sonoros. Se puede definir como un conjunto de preceptos y reglas necesarios para hacer bien cualquier cosa. Cuando hablamos de cine y el resto de las seis artes, nos referimos a las bellas artes las cuales tienen la finalidad de resaltar la belleza.

El cine, como el arte de contar historias por medio de imágenes y sonidos; infunden deleite, diversión, reflexión y placer. Se caracteriza por comprender altos niveles de valores económicos y estéticos; los primeros porque al comercializarse, generan ingresos y utilidades; mientras que los segundos se refieren a esta característica inherente del séptimo arte por buscar el equilibrio cognitivo y sensitivo y la belleza interna y externa. 
Como obra de arte, el cine represente un reto para las OPC, pues al pretender transmitir ideas y pensamientos a los espectadores, que les impacten, es difícil. Se necesita experiencia. Esto se ve reflejado cuando el Anuario Estadístico de Cine Mexicano muestra que sólo hubo 53 óperas primas para el 2015; 54 para aquellos directores con dos o tres películas y 37 para aquellos que han dirigido más de cuatro.

Los festivales de cine, orientados a espacios artísticos, permiten la interacción entre cineastas, OPC, distribuidores y exhibidores. El agrado para los espectadores resulta evidente al incrementarse el número de los mismos; en 2000 sólo se celebraban 10 mientras que para el 2015 se registró un número de 119. Las películas con temas relacionados con religión y el medio ambiente y los cortometrajes de temas varios fueron los que obtuvieron mayor proyección.

El cine funciona como herramienta cultural al transmitir conocimientos, fomentar el espíritu crítico y estimular el diálogo. Su carácter se plasma en tres sentidos: físico por su funcionamiento; histórico, ya que revela la relación que se da entre los personajes y las fuerzas socioculturales; y sicológico porque el director transfiere su identidad. El arte y la cultura se transmiten por diferentes géneros como las historias de amor, horror, época, guerra, drama social, histórica, arte y ensayo, entre otros.

Los espectadores esperan de las películas proyectadas en salas de arte aprender sobre el tema que se aborda, adquirir nuevas ideas y opiniones, retener temas, fomentar las artes y reflexionar sobre los problemas que aquejan a la sociedad. Por otro lado, el cine como obra de arte propone principios, formas eternas, arquetipos, meticulosidad, el realismo, conciencia, respeto y la originalidad.

En general, los resultados del presente estudio arrojaron que no existe una correlación entre los deseos que un espectador tiene por que se proyecten en salas de arte, películas que estimulen entre los espectadores el aprecio a las artes y estética cinematográficas, la reflexión de los contenidos de las películas, el aprendizaje y el entretenimiento con el gasto que destina dicho espectador para ver películas que antepongan el entretenimiento sobre cualquier otra cosa en el cine.

Lo mismo sucedió para aquellos que antepusieron el carácter educativo y cultural, el carácter artístico y el carácter de estimulación de la reflexión. El consumidor gastará la misma cantidad de dinero para ver filmes que principalmente fomenten el aprecio a la estética cinematográfica sin que le importen si dichas películas exhibidas en salas de arte estimulan, o no, las cuatro características 
del cine antes mencionadas entre los demás miembros del público. Es decir, los consumidores no condicionan la compra de boletos en taquillas a si las OPC estimulan, o no, el arte, reflexión, entretenimiento o educación en los demás.

\section{Referencias}

Adelsolean, A. (2014). Visiones de Lagos: urbanismo didáctico en el cine de Nollywood. Universidad Católica de Maule. Chile: Bifurcaciones, revista de estudios culturales urbanos, 17, 1-16.

Alvarado, C. (2015). El régimen estético en las imágenes en movimiento de la filosofía de Jaques Ranciére al cine de Béla Tarr. Universidad de Zulia: Colomia. Revista de Filosofía, 81(3), 49-71.

Amar, V. (2009). El cine en la encrucijada de la educación y el conocimiento. Enlace. Venezuela: Revista Venezolana de Información, Tecnología y Conocimiento, 2(6), 131-140.

Anuario Estadístico de Cine Mexicano 2015. IMCINE, México.

Arrese, Á. (2004). Algunas consideraciones sobre la gestión de productos y contenidos de los medios. Comunicación y Sociedad, 15(2), 9-44.

Arias, J. (2006). El cine como realización del fin del arte. Pontificia Universidad Javieriana: Colombia. Revista Signo y Pensamiento, 49,100-111.

Badii, M., A. Pazhkh, J. Abreu \& R. Foroughbakhch (2004). Fundamentos del Método Científico. UANL: México. InnOvaciOnes de NegOciOs 1(1), 89-107

Cárdenas, J. (2014). Anotaciones sobre el fetiche cultural y el cine. Universidad de la Sabana. Colombia: Palabra Clave, 17(3), 619-644.

Dale, E. (1966) Métodos de Enseñanza Audiovisual. México: Reverte.

Fajnzylber, V. \& J. Hurriaga (2013). Usos educativos del cine 3D estereoscópica. Ensayos: Chile. Chasquis, 122, 96-102.

Flores, A., M. Gómez \& B. Sierra (2009). Apreciación a lo artístico: lo visual y auditivo en la cotidianidad urbana. México. Grupo Editorial Patria.

Galán, M. (2012). Cine militante y videoactivismo: los discursos audiovisuals de los movimientos sociales. Universidad Complutense: España. Revista Internacional de Comunicación Audiovisual, Publicidad y Estudios Culturales, 10, 1122-1133.

García, M. (1997). Cine, narrative y enseñanza de la filosofía. Universidad Nacional de Educación a Distancia. España: Revista Española de Pedagogía, 207(97), 303-316.

García, M. (2002). Historias de hombres y mujeres en términos de luz: el papel del cine en la educación. Aportes de discusión. México. Revista Mexicana de Investigación Educativa, 7(15), 357-369.

Gómez, A. \& H. Estrada (2015). El cine y la comunicación de malas noticias. Universidad de Salamanca. España: Revista Medicina Cine, 12(1), 21-32. 
González, G. (2013). El cine como herramienta didáctica educativa en el contexto literario. Universidad Autónoma de Nuevo León. México. Tesis para obtener el grado de Maestría en Ciencias de la Comunicación.

Keizman, B. (2011). Borges, el cine y las estrategias de representación. Universidad Diego Portales. Chile: Revista de Crítica Literaria Latinoamericana, 73, 253-269.

Lozano, D. \& E. Treviño (2014). Arte, cultura o entretenimiento en el cine: ¿Qué modelo cinematográfico prefieren los espectadore para romar la decision de asistir a ver una película? UANL. México: InnOvaciOnes de NegOciOs, 11(22), 269-295.

Lozano, D. (2015). La producción de series de televisión por las Organizaciones de Producción Cinematográficas (OPC) como herramienta educativa. Caso de studio CSI: Miami. Spenta University: México. Daena: International Journal of Good Consciences, 10(2), 196-219.

Lozano, D.; A. Almaguer \& K. Rodríguez (2015). La promoción de los valores sociales por las organizaciones de producción cinematográficas para crear comunidades de paz en México. Spenta University: México. Daena: International Journal of Good Conscience, 10(1), 19-50.

McKee, R. (2011). El guión. Alba Minus. Colombia.

Platón (2009) Diálogos. México. Editorial Porrúa.

Quevedo, V. (2011). La voz del cine africano desde sus orígenes al presente. Universidad de Alicante. España. Quaderns de cine, 7, 7-16.

Sancho, J., A. Vilchis \& D. Gil. (2010). Los documentales científicos como instrumentos de educación para la sustentabilidad. Asociación de Profesores Amigos de CienciaEureka. España: Eureka sobre Enseñanza y Divulgación de Ciencias, 7(3), 667-681.

Surmeli, H. (2012). Examination the effect of science fiction films on science education students. Procedia social and behavioral sciences, 47, 1012-1016.

Zorroza, M. (2007). Ficción, experiencia y realidad. ¿Qué tiene que ver el cine con la vida? Universidad de Piura. Perú. Revista de Comunicación, 6, 70-80. 